\title{
Land use options and crop suitability of some red soils, red laterite soils and black soils of semi arid region of Tamil Nadu
}

\author{
RAJESHWAR MALAVATH AND S. MANI
}

Received : 24.12.2014; Revised : 02.04.2015; Accepted : 11.04 .2015

\author{
MEMBERS OF RESEARCH FORUM \\ Corresponding author : \\ RAJESHWAR MALAVATH, \\ Department of Soil Science and \\ Agricultural Chemistry, College of \\ Agriculture, Professor Jayashankar \\ Telangana State Agricultural \\ University, Rajendranagar, \\ HYDERABAD (TELANGANA) INDIA \\ Email: rajeshoct31naik@gmail.com
}

Co-authors :

S. MANI, Department of Soil Science and Agricultural Chemistry, Agricultural College and Research Institute, Tamil Nadu Agricultural University, COIMBATORE (T.N.) INDIA

\begin{abstract}
Summary
The study was carried out in the three new research stations of Tamil Nadu Agricultural University with varied soil types viz., Maize Research Station, Vagarai of Dindigul district, Cotton Research Station, Veppanthatai of Perambalur district and Dryland Agricultural Research Station, Chettinad of Sivagangai district of Tamil Nadu were selected for developing the strong soil resource database for proper appraisal of their productivity potential and their rational use. This study was an embodiment with an objective of land use options and crop suitability of some red soils, red laterite soils and black soils of semi arid region. Land capability classification was done based on the inherent soil characteristics, external land features and environmental factors. There are two land capability classes with five subclasses in the study area, viz., 'IIItsef', 'IIIswf', 'III swef', 'IVtsef' and 'IVtsdef'. The red soils of MRS, Vagarai were marginally suitable to highly suitable for cultivation of maize, greengram, sorghum, redgram and blackgram. The black soils of CRS, Veppanthattai were moderately suitable to highly suitable for cultivation of cotton, sorghum, soybean, greengram, blackgram, redgram, sunflower, sesamum, maize and pearlmillet. The red laterite soils of DARS, Chettinad were marginally suitable to moderately suitable for cultivation of groundnut, greengram, blackgram, redgram, horsegram and pearlmillet.
\end{abstract}

Key words : Land use options, Crop suitability of some red soils, Red laterite soils, Black soils of semi arid region

How to cite this article : Malavath, Rajeshwar and Mani, S. (2015). Land use options and crop suitability of some red soils, red laterite soils and black soils of semi arid region of Tamil Nadu. Asian J. Soil Sci., 10(1) : 13-22. 